\title{
Determinants of ownership concentration in the Chilean stock market
}

\author{
Marco Morales, Maria José Meléndez and Vanessa Ramírez
}

ABSTRACT

This paper analyses econometrically the determinants of ownership concentration in the Chilean stock market, paying particular attention to the effects of the Public Tender Offer Act (Ley de Ofertas Públicas de Adquisición de Acciones). Although the Public Tender Offer Act achieves its central purpose, the tender offer mechanism increases the concentration of ownership, mainly because of the "residual tender offer" obligation for which the Act provides. In addition, the study has found significant opposite responses between the controlling shareholder and the next two largest shareholders, which should sound a warning for international comparisons based on a common measure of ownership concentration that do not take account of the ownership structures characterizing Latin American markets. These aspects must be considered if the regulatory goals aimed at by minority shareholder protection bills are to be achieved.

KEYWORDS

JEL CLASSIFICATION

AUTHORS
Shares, markets, economic concentration, laws and regulations, econometric models, Chile

G32, G34, G23

Marco Morales, Associate Professor, Department of Economics, Universidad Diego Portales, Santiago, Chile. marco.morales@udp.cl

María José Meléndez, Analyst, Infrastructure and Financial Regulation Management, Central Bank of Chile.mmelendez@bcentral.cl

Vanessa Ramírez, Analyst, Financial Stability Management, Central Bank of Chile. vramirez@bcentral.cl 


\section{I}

\section{Introduction}

Many studies have analysed the determinants of ownership concentration. Thus, Demsetz and Lehn (1985) argued that the structure of corporate ownership was explained by firm size, the instability of profits, whether or not the firm concerned was a regulated utility or financial institution, and whether or not it was in the mass media or sports industry. They also found that large publicly traded corporations were frequently characterized by highly diffuse ownership structures that effectively separated ownership of residual claims from control of corporate decision-making. On the basis of these findings, Weiss and Richter (2010) have recently studied the relative importance of firm-, industry- and countrylevel factors as determinants of the level of company ownership concentration. They have found that firm- and country-level factors, especially the institutional context, influence ownership concentration significantly, rather than industry-level factors.

In a similar context, the law and finance literature has extensively analysed the relationship between ownership concentration and legal protection for minority shareholders. At the empirical level, statistical evidence indicates that ownership is more concentrated on average in countries where legal protection is weaker. Following La Porta and others (1998) and La Porta, López-deSilanes and Shleifer (1999), when legal protection is weak, ownership concentration provides a substitute for investors, given that large shareholders have a greater likelihood of achieving a positive return on their investments. Conversely, investors appear to be willing to take minority positions and to finance firms in countries where legal rules exist and are effectively enforced.

However, the concept of weak or strong legal protection is not always a clear one. The papers cited above also suggest that better accounting standards reduce ownership concentration, while mandatory dividend payments increase it. In the same area, Faccio and others (2001) analyse dividend policies in several countries of Asia and Europe, finding that concentration

\footnotetext{
$\square$ We are grateful to Rodrigo Bravo and especially to Juan Ignacio Zucal for their outstanding research assistance in building and cleaning up the database for this study. We also appreciate the comments and suggestions of Francisco Silva, Guillermo Yáñez and Guillermo Larraín. Any remaining errors are our own.
}

is higher in European countries even though firms there pay proportionally larger dividends than firms in Asian countries. If we consider that higher dividends are associated with better legal protection, then there will not be an inverse relationship between concentration and legal protection for shareholders as the empirical evidence suggests.

This contradiction could be solved by the arguments presented by Burkart and Panunzi (2006). That paper looks beyond the popular idea that legal protection reduces the likelihood of managers diverting resources from the firm and considers the relationship between the quality of legislation and the incentives for shareholders to monitor managers. Thus, when legislation offers a substitute for monitoring, legal protection for shareholders could increase ownership concentration rather than reducing it as, on average, the empirical evidence suggests. On the other hand, ownership concentration appears to depend on a trade-off between manager initiative and shareholder monitoring that is directly associated with the legislation. Again, there is more monitoring in countries with strong legal protection, and ownership concentration is not required to protect shareholders. Hence, while some rules or laws are complementary to monitoring, others are substitutes, giving rise to this direct relationship between legal protection and ownership concentration that contradicts the average empirical evidence.

Musacchio (2007) analyses the historical evolution of ownership concentration and legal protection for minority shareholders in Brazil. His work mainly focuses on the effects of voting systems limiting power to larger shareholders, on regulations ensuring the payment of dividends and on ownership concentration for firms where ownership is dispersed. Although the results are not statistically conclusive, there is some evidence to support policies limiting voting rights for larger shareholders and providing legal protection for minority shareholders, with the objective of reducing ownership concentration.

From the perspective of corporate governance in Europe, Kim and others (2008) demonstrate the hypothesis that shareholder protection rights and board independence are positively related. The results show that countries with stronger shareholder protections have firms with more independent directors. These are thus complementary 
governance mechanisms, so ownership concentration and board independence are negatively related.

From the point of view of the relationship between corporate ownership and initial public offerings (IPOs), Foley and Greenwood (2010) analyse panel data on corporate ownership in 34 countries between 1995 and 2006 to test the relationship between ownership concentration and weak investor protection. Their results reveal that newly public firms tend to have concentrated ownership regardless of the level of investor protection. They also show that, after listing, firms in countries with strong investor protection are more likely to experience decreases in ownership concentration in response to growth opportunities.

This paper analyses econometrically the determinants of ownership concentration in the Chilean stock market, paying particular attention to the effects of the Public
Tender Offer Act (Ley de Ofertas Públicas de Adquisición de Acciones). Section II begins with a description of the main variables commonly cited in the literature as determinants of ownership concentration. Section III presents a discussion on pyramidal ownership structures as alternative control schemes to the one considered in this study. Section IV looks at the role of institutional investors in corporate governance in terms of monitoring managers and the main shareholders. Section V outlines the basic features of the Public Tender Offer Act, considering how it protects the interests of minority shareholders when control of a firm changes hands. Section VI presents the econometric analysis, including a description of the dataset and the results of the estimation. Lastly, section VII presents the conclusions derived from the empirical evidence and discusses the research agenda for future work.

\section{II}

\section{Determinants of ownership concentration}

Besides the existence and quality of laws dealing with corporate governance and protection for minority shareholders, firm-specific factors (size, financial ratios, etc.) and aggregate variables (market capitalization and liquidity, per capita income, etc.) should also be treated as potential determinants of ownership concentration in the market.

Although empirical analysis of these determinants should be based on the specification of a function derived from first principles (first-order conditions from a utility maximization problem solved for shareholders and their interaction), most of the statistical evidence comes from cross-sectional studies for several countries that include variables which might affect ownership concentration, but without any consistent model-building approach.

Among the firm-specific variables usually treated as determinants of ownership concentration are size, leverage and dividend policy.

A first argument says that the larger the firm, the greater the number of shareholders required to create the stock of capital, and the more dispersed ownership must be. In most countries (the exceptions being the United States, the United Kingdom and Japan), however, firms are usually controlled by families or even individuals and there is no significant deviation from the "one share, one vote" rule (i.e., voting rights are proportional to ownership stakes), the implication being that control is obtained mainly through ownership concentration, with any equity increase coming from larger shareholders rather than from a greater participation by minority shareholders, so that ownership concentration is increased.

Second, a higher level of debt (measured by financial leverage) indicates better access to bank and bond financing, reducing the need for a larger number of minority shareholders when it comes to financing new investment projects. Thus, greater leverage may be directly related to ownership concentration.

In addition, dividend policy is considered to be a protection mechanism for minority shareholders, given the potential for expropriation by controlling shareholders. In fact, policies providing for minimum dividend payout percentages could be seen as substitutes for specific legal protection for small shareholders. The larger the dividend payment percentage (above the legal minimum, where one exists), the larger the number of minority shareholders willing to involve themselves with the company. Thus, ownership concentration should be inversely related to dividends. However, as discussed in the Introduction, the relationship could be a direct one if the dividend payout policy results in less monitoring by shareholders. 
Pension funds are minority shareholders by definition because of regulatory limits on their investments. However, given that these institutional investors have teams of well-trained financial analysts, while it is possible for several funds to vote as a block to secure a seat on the board, they are in a position to monitor managers and perhaps to improve the corporate governance of the firms they invest in. All these actions may induce greater dispersal of ownership by reducing the control premium for large shareholders or giving minority shareholders greater confidence to participate. The role of pension funds could be particularly important in the Chilean case because of the large volume of funds accumulated since the start of the private pension system in the early 1980s.

In terms of aggregate variables (common to all firms), a stock market that is deep and wide (as measured by market capitalization to GDP) should make it easier for minority shareholders to invest in firms, helping to reduce ownership concentration. Similarly, per capita GDP (as a proxy for average income) should have a direct relationship with the number of minority shareholders, helping to reduce concentration.

Along with the above, a number of factors must be taken into account in efforts to reduce ownership concentration, as they can generate unexpected negative effects if they are not considered. In this regard, the first consideration is that corporate governance at an appropriate management level is essential to control associated agency costs.

The importance of the corporate governance issue has been debated worldwide for over a decade, and particularly since 2007 and the financial crisis, which only served to expose a series of failures in the governance of financial institutions.

This led to the 2010 review by the Basel Committee on Banking Supervision of the so-called principles for enhancing corporate governance, ${ }^{1}$ which took into consideration the recommendations previously made by the Organisation for Economic Cooperation and Development (OECD, 2004). In particular, corporate governance is defined as one of the key elements for improving economic efficiency and growth and for promoting confidence among market participants.

Also dealing with financial regulation and consumer protection, and published in the same year in the United States, was the Dodd-Frank Wall Street Reform and Consumer Protection Act, aimed at promoting financial stability in the country, the transparency and accountability

1 See [online] http://www.bis.org/publ/bcbs176.pdf. of its financial system and protection of taxpayers and consumers from potential abuse. The key points of this new reform include strengthened corporate governance and the management of conflicts of interest, and it establishes the important role played by the board of directors in monitoring each company.

Meanwhile, as discussed below, Chile introduced the topic of corporate governance in its so-called Public Tender Offer Act in 2000 and later, in 2009, with the passing of Law No. 20382, which "introduces improvements to the rules governing the corporate governance of companies". This statute enacted amendments to Law No. 18045 and Law No. 18046 with a view to protecting the rights of shareholders in corporations, encouraging transparency and information provision and establishing the important role the board plays in achieving this. It added a new section on related party transactions, defining what is meant by such operations, the requirements for carrying them out and the reporting obligations for them to be approved by the board of directors, in accordance with certain stipulations. ${ }^{2}$ This change was made to facilitate the identification of potential conflicts of interest that may arise when such operations are conducted.

Furthermore, given the characteristics of ownership concentration in Chile, with most directors being people who have ties to the controlling group of the company, the law requires the appointment of at least one independent director. This plays an important role in improving the management of companies and could ultimately increase their value (Lefort and Urzúa, 2008).

In relation to insider dealing, the law establishes that company employees who are aware of insider information may not buy or sell stocks until the information is released. This is what is known as a blackout period. The law also makes a distinction between the presumption of possession of insider information, which applies to those who work within the company management, and the presumption of access to information, which applies to those who interact with the management without being part of it. These improvements are very important given the ownership structure of Chilean companies, as there may be greater potential for misuse of insider information in this case.

\footnotetext{
2 According to article 147 of Law 18046, the requirements and procedures laid down may be waived for some related party transactions, such as those not involving substantial sums, those deemed to be a routine part of the company's business and those carried out between legal entities when the company owns at least $95 \%$ of the counterparty, either directly or indirectly.
} 
In summary, the establishment of an appropriate governance system creates the right incentives for both the management and the board of directors to run the company properly and for effective monitoring and timely protection of stakeholders. Nevertheless, there is a further factor that can potentially affect ownership concentration for companies: their structure. In the next section, we analyse the implications for Chilean firms.

\section{III}

\section{Pyramidal structures}

This study analyses ownership structure purely on the basis of the percentage of companies owned by their controlling shareholders. In other words, it assumes that company control is exercised through "one share, one vote", implying that voting rights are proportional to share ownership. In fact, many public-sector enterprises in developing countries that form part of business groups are characterized by the separation of voting rights from cash flow rights through the use of cross-shareholdings, stock pyramids and multiple-class equity, allowing owners to gain effective control of their firms with limited cash flow rights.

In a pyramidal structure, the controlling family achieves control through a chain of ownership relationships: the family directly controls a company, which in turn controls another company, which may control another company, and so on. For example, a family at the top of a pyramid may own $50 \%$ of a company that in turn owns $50 \%$ of another firm, which owns $50 \%$ of a third firm, thereby achieving control of all firms in the pyramid with an increasingly small investment in each firm down the line. In this way, the ultimate shareholder maintains control of the companies without being entitled to the cash flows they generate, so that pyramids are a distortion of the principle of "one share, one vote".

This distortion could affect our analysis, since we are considering only the ownership percentage of the controlling shareholders in a firm. In other words, we may not obtain the results expected if pyramidal structures prove to be very important in the Chilean market. This section will therefore discuss the operation of pyramidal structures and their presence in the Chilean market.

La Porta, López-de-Silanes and Shleifer (1999) define the ownership structure of a company as a pyramid if it has an ultimate owner and there is at least one publicly traded company between it and the ultimate owner in the chain of $20 \%$ voting rights. Thus, if a publicly traded firm B has $45 \%$ of the votes in a firm A, and an individual $\mathrm{C}$ has $30 \%$ of the votes in firm $\mathrm{B}$, we would say that $\mathrm{C}$ controls $\mathrm{A}$, and that the ownership structure is a pyramid.

Figure 1 shows how ownership is separated from control by using pyramidal structures in a business group. The holding company has effective control of all the firms in the pyramid, while actually owning an ever-smaller portion of each firm. For example, while the holding company receives $100 \%$ of dividends paid by companies $\mathrm{A} 1$ and $\mathrm{B} 1$ and $70 \%$ of those paid by company $\mathrm{C} 1$, it receives only $34.3 \%$ of the dividends paid by company $\mathrm{G} 3$.

La Porta, López-de-Silanes and Shleifer (1999) examined the ownership structures of large corporations in 27 developed economies around the world and found

FIGURE 1

An example of pyramidal ownership

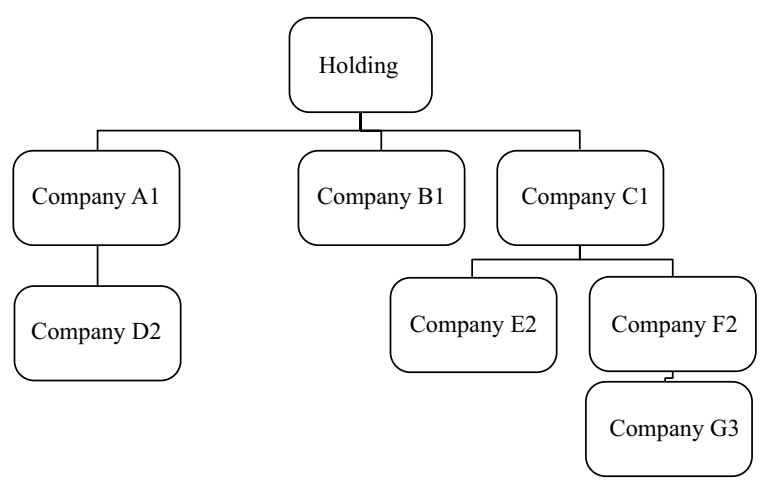

Source: F. Lefort, "Hacia un mejor gobierno corporativo en Chile", Temas de la agenda pública, year 3, No. 23, Santiago, Chile, Catholic University of Chile, 2008. 
that $26 \%$ of firms were controlled through pyramids; also, this structure appeared to be the most important mechanism used by controlling shareholders to separate ownership of cash flows and control rights. Claessens and others (2000) examined companies in nine Asian countries and found that the use of pyramidal structures was quite common there. Faccio and Lang (2002) reported that the use of dual-class shares and pyramids to enhance the control of the largest shareholders was common in Western Europe, and Khanna and Yafeh (2007) found that these structures were more often present in emerging markets.

Like other Latin American countries, Chile has a high concentration of ownership and a corporate structure dominated by clusters. In Chile, corporate groups seek control basically through pyramidal structures, mainly because cross-shareholdings are prohibited under Chilean law. Sometimes these pyramids have several layers of investment companies before the level of operational firms is reached. The latter may also control several individual companies, sometimes in unrelated sectors of the economy. ${ }^{3}$ Lefort and Walker (2000 and 2007) have shown that approximately $70 \%$ of non-financial companies listed in Chile belong to one of 50 clusters, which together control $91 \%$ of the assets of nonfinancial corporations in the country. They suggest that the most common way of separating control from cash flow rights in Chilean conglomerates is though simple pyramidal schemes, with only a third of the affiliated companies listed on the second and third levels of the pyramid structure. They also show that the controlling shareholders of Chilean conglomerates have more shares than are necessary to maintain control, with $57 \%$ of consolidated capital being directly or indirectly owned by them in 1998 .

\footnotetext{
3 See Agosin and Pastén (2003).
}

\section{IV}

\section{Institutional investors and corporate governance}

Another aspect that has gained in importance recently is the role that institutional investors, and particularly pension fund administrators (AFPS), might have in improving and promoting good corporate governance practices in the companies they invest in. According to the Organisation for Economic Cooperation and Development (OECD), despite the limitations on investment opportunities in Latin America, institutional investors are playing a leading role in stock market growth as the largest and most influential minority shareholders in many listed companies, so that "pension fund governance and accountability...remains an important public policy priority for the region" (OECD, 2010).

The interest of institutional investors in promoting corporate governance is further underscored in markets with a high concentration of ownership. Investors of this type act as a counterbalance to the controlling shareholders and protect minority shareholders against the interests of the company board or management, other than those that serve the interests of the company and its shareholders as a whole. In the case of pension funds, the social role and vigilance exercised to protect the future benefits of retirees should be correspondingly stronger.

Pension system reforms, starting with Chile in 1981 and continuing in the 1990s with many other Latin American countries, have made a large contribution to growth in domestic pools of investment funding. The half-yearly statistics for pension funds in Latin America show that such funding in Chile amounts to $60 \%$ of GDP.

As was pointed out in the previous section, the Chilean market is characterized by the existence of financial conglomerates and pyramidal structures, ${ }^{4}$ while regulations prevent pension funds from controlling firms. They are the main minority shareholders in Chilean companies, investing a large share of their resources

\footnotetext{
4 As Lefort and Walker (2000) showed, pyramidal schemes are the most common way of achieving control in Chilean conglomerates, since cross-shareholdings are forbidden by law and dual-class shares are relatively rare.
} 
in local shares. In fact, according to Agosin and Pastén (2003), "a specific feature of Chilean capital markets is the existence of well-developed institutional investors, specifically the private pension managers that arose from the pension reform of 1981 where in spite of the limitations imposed upon the AFPs in the kinds of investments they can make, they have been responsible for a significant deepening of the stock market". This indicates the importance of investors of this type, given their potential influence over corporate governance and corporate ownership structures, as well as over the regulation and depth of capital markets.

Accordingly, Iglesias-Palau (2000) studied the influence of Chilean pension fund administrators (AFPS) on corporate governance. He established that AFP involvement in the stock market had had positive effects on corporate governance in several respects, including: an increase in the number of independent board members; a decrease in monitoring costs as a result of improved public information quality; enhanced supervision of companies that pension funds had invested in; and improved bondholder protection. More recently, Lefort (2007), analysing the channels through which the AFPs may be having an effect, directly or indirectly, on the quality of corporate governance at Chilean companies, has concluded that this effect is positive, particularly in relation to three issues: (i) the emergence of reform in the legal system and the improvement of the oversight under which firms operate, which have influenced the quality of the external mechanisms regulating corporate governance; (ii) the emergence of greater capital market liquidity with growing funding and trading volumes; and (iii) the professionalization of financial intermediaries and the adoption of more advanced and cost-efficient transaction methods. After analysing various interventions by the AFPs to improve the corporate governance practices of corporations in which they have invested their resources, the author emphatically concludes that direct monitoring and intervention by AFPs exercising their rights as minority shareholders, bondholders or both has helped to improve firms' internal corporate governance mechanisms.

Starks (2000) and Gillian and Starks (2003) examine the relationship between corporate governance and ownership structures, focusing on the role of institutional investors. They examine cross-country differences in ownership structures and the implications of these differences for institutional investor involvement in corporate governance. They conclude that despite these differences across markets, institutional investors have the potential to play an important role. On balance, they expect an increase in the liquidity, volatility and price informativeness of the markets in which institutional investors invest and, consequently, the increased information provided by institutional trading should result in better monitoring of corporations and in better corporate governance structures. Regarding the influence of international institutional investors on governance, Aggarwal and others (2009) examine whether institutional investors affect corporate governance by analysing institutional holdings in companies from 23 countries for the 2003-2008 period. Their finding is that firm-level governance is positively associated with international institutional investment. They also establish that the origin of the institution matters, as institutions domiciled in countries with strong shareholder protection are more effective at promoting good governance than institutions from countries with weak shareholder protection.

From another point of view, Davis (2002) separated the discussion of the growing dominance of equity holdings by institutional investors into two groups: the Anglo-Saxon countries (the United Kingdom, the United States and Canada) and continental Europe and Japan (Germany, France, Italy and Japan). He found that the former countries were showing an increase in the direct influence of institutions in place of the previous reliance on the takeover mechanism to discipline managers, and thence improved corporate performance, while the second group of countries remained more firmly within the bank relationship-based governance paradigm. On this subject, though, Rojo and Garrido (2002) have argued that these types of differences in the structure of corporate governance systems lead to differences in the nature of the problems and in the solutions available to them. According to these authors, institutional investors can provide a solution to the problem of dispersed share ownership, but this solution needs to be accompanied by a host of regulatory changes, while regulatory changes are even more necessary in the case of continental systems of corporate governance, because otherwise institutional investors will tend to aggravate the corporate governance problem. 


\section{$\mathrm{V}$}

\section{The Public Tender Offer Act}

The Public Tender Offer Act, published in Chile in December 2000, regulates changes in corporate control via a tender offer mechanism, identifying situations in which an offer must be made, the information to be disclosed to shareholders, the period of time for which the offer must remain open and the pro rata conditions that apply whenever a tender offer generates a surplus supply of shares. In addition, the law establishes the conditions under which a tender offer is not mandatory and provides for a three-year transition period during which control may change hands without recourse to the tender offer mechanism.

The tender offer mechanism gives all shareholders the same price and the same opportunity to sell their shares to the new controlling shareholder, who notifies the percentage being sought and the time period during which the offer will be open. In addition, the buyer must indicate the pro rata conditions for share allocation when supply exceeds demand, to ensure that all shareholders have similar opportunities to sell shares to the controlling shareholder.

When analysing ownership concentration, it is interesting to highlight the role of "residual tender offers" whenever the controlling shareholder obtains two thirds of voting rights (shares representing that percentage), irrespective of whether they have been obtained by a tender offer or any other acquisition mechanism. The consideration underlying this residual tender offer obligation is that, with two thirds of voting rights, the controlling shareholder can govern the company unopposed, even in the case of actions requiring a qualified quorum. The obligation could also be justified by considering the reduced liquidity faced by minority shareholders once just a third of the company is traded on the market, and the corresponding liquidity premium affecting prices. In this latter situation, however, the law includes a right for minority shareholders to withdraw by selling their shares to the firm at the average market value for the previous two months.

Overall, the main feature introduced by the Public Tender Offer Act for the protection of minority shareholders is the inability of large shareholders to receive a "control premium" when selling their stakes, as the mechanism makes the same conditions available to all shareholders, whatever percentage of the company they may own.

\section{VI}

\section{Econometric analysis}

\section{Data description}

The dataset includes 67 firms listed on the Santiago Stock Exchange during the 1990-2007 period. Although the total number of listed firms was larger, we excluded companies in which the State held a significant stake, firms with low or zero trading volumes and firms with incomplete or unreliable data.

To measure ownership concentration, the international literature usually takes the sum of the three largest shareholders, considering that companies in countries like the United States, the United Kingdom and Japan are widely held. In Chile, however, the main shareholder owns almost half the company on average, with the second-largest shareholder owning one seventh and the third-largest one sixteenth. Taking the sum of the three largest shareholders assumes some homogeneity of behaviour between them, but in fact they could show totally different responses to the variables determining ownership concentration.

As regards independent variables, corporate equity is measured in millions of Chilean pesos at constant 2003 prices, while financial leverage is calculated as total debt divided by equity as of December each year. 


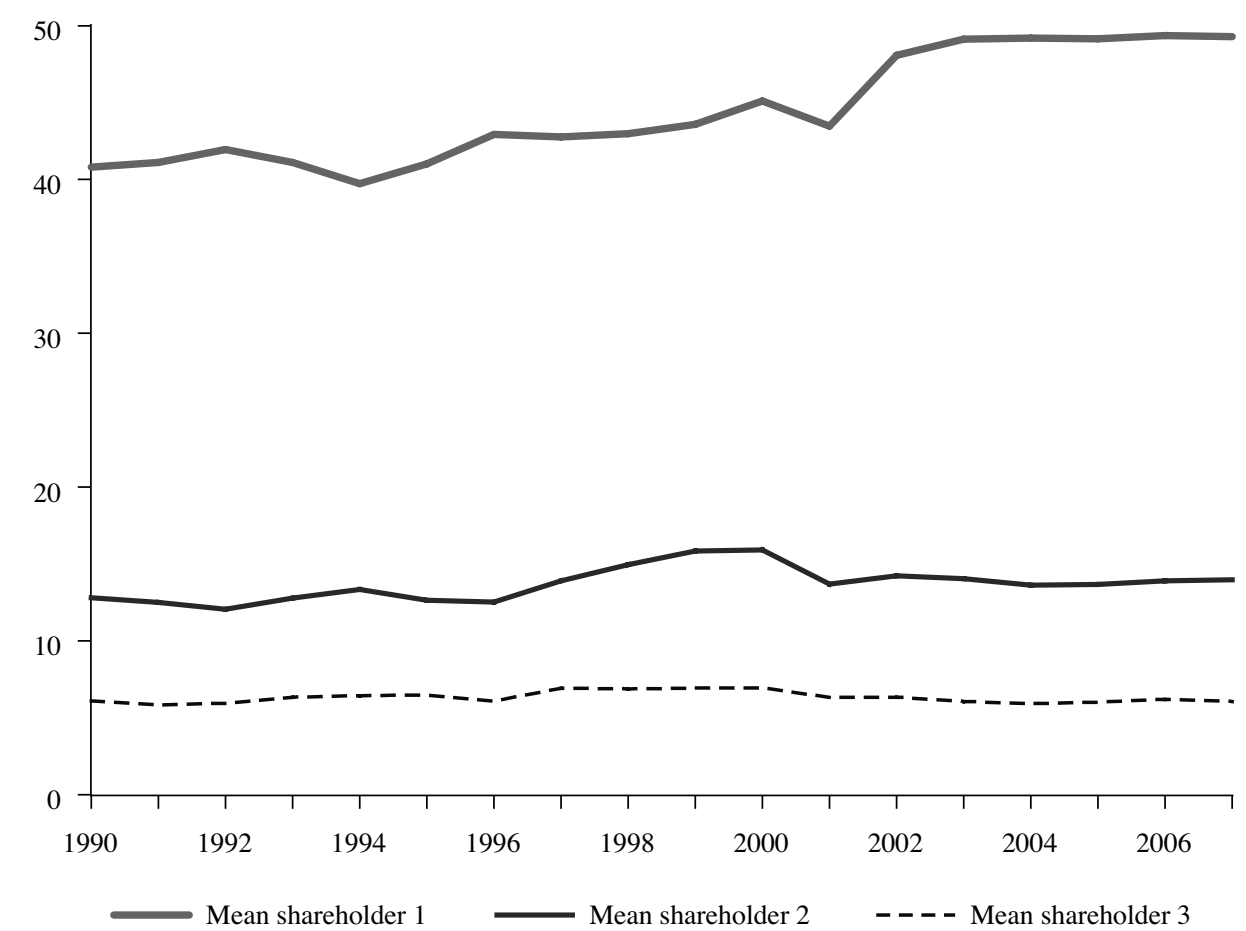

Source: prepared by the authors on the basis of data from the Office of the Superintendent of Securities (SVS).

Given the mandatory dividend payout of $30 \%$ of the previous year's earnings, this variable indicates the payout in excess of that minimum.

The pension funds variable measures the overall share of the group of AFPs, provided they are among the top 10 shareholders in the firm. Aggregate variables such as market capitalization to GDP and per capita GDP are all measured at constant 2003 prices.

Figure 3 looks at the size (equity) of companies and shows that the distribution is less skewed towards small companies by the end of the sample. The average size in 1998 and 2007 is between US\$ 100 million and US\$ 500 million.

\section{Panel estimation}

The following specification is estimated by fixed-effects panel methods, taking four alternative shareholder shares as the dependent variable:

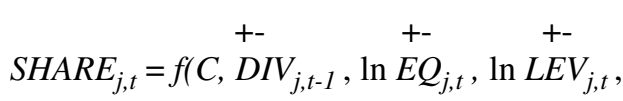

$$
\begin{aligned}
& \text { ln } G D P_{-} P C_{j, t}, M C_{-} G D P_{j, t}, \stackrel{-}{P F_{j, t},} \stackrel{+-}{+-} \text {, } \\
& +-\quad+ \\
& \left.\operatorname{TRANS}_{j, t}, \operatorname{SHARE}_{j, t-1}\right)
\end{aligned}
$$

Dividends are lagged one period to avoid potential endogeneity, since payout policy may depend on ownership concentration.

The effect of the Public Tender Offer Act is represented by a dummy variable taking a value of 1 for the year 2001 onward and 0 otherwise. The transition period is represented by a second dummy variable equal to 1 for the year 2001 and 0 for the rest of the sample. In this latter case, it only made sense to relinquish control outside of the tender offer mechanism during the first year, since a larger premium would have to 
FIGURE 3

Size distribution of companies, 1990, 1998 and 2007

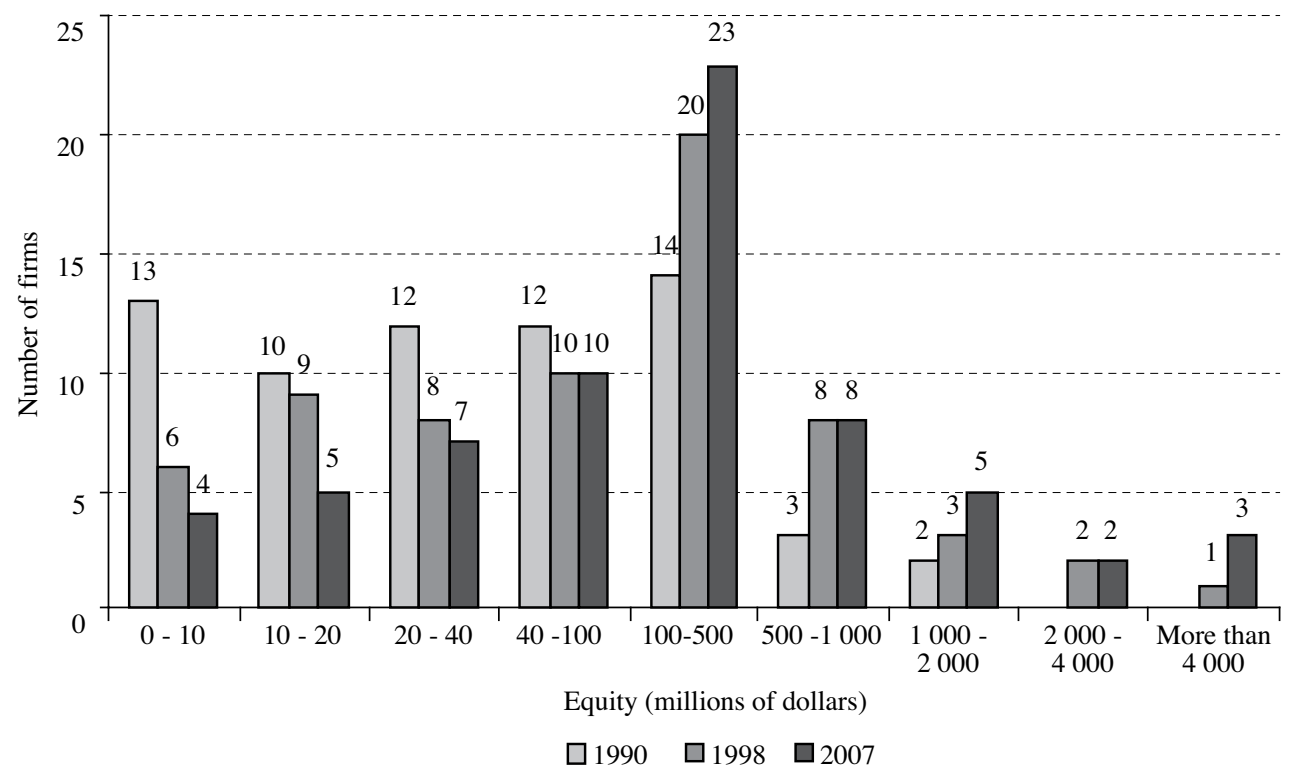

Source: prepared by the authors on the basis of data from the Office of the Superintendent of Securities (SVS).

be paid for doing this later in the transition period (the reputational cost in the eyes of domestic and foreign institutional investors was assumed to rise over the transition period).

The lagged dependent variable is included to take account of autocorrelation in the error term. The resulting dynamic panel model is consistently estimated by a fixed-effects method, since the bias in the autoregressive coefficients falls towards zero (0) as the time series observations tend towards infinity. Meanwhile, the rest of the parameters are unbiased provided the independent variables are strictly exogenous.

\section{Estimation results}

The following table presents the econometric results for each of the four dependent variables used as measures of ownership concentration. The first column contains the regression model for the popular definition taking the top three shareholders. The next three models consider the first, second and third shareholder in order to check if the inference from the popular analysis is appropriate for the Chilean case.

Although some of the independent variables in the model present potentially non-stationary behaviour (if only in the form of a deterministic trend in the long run), the shareholder share is a stationary variable in any definition we choose. There was thus no risk of any spurious correlation in our estimation that might invalidate the analysis from the results obtained. Moreover, not controlling for potential trends in some of the exogenous variables makes the present econometric analysis more demanding on our model specification.

As can be seen from the estimation results above, dividend policy reduces ownership concentration for the first shareholder (and for the top three) while increasing it for the second (for the third, the coefficient is no different from zero $(0))$. There is a similar contradiction in the level of equity, with a direct relationship for the first and top three shareholders but a negative one for the second and third. Similarly, AFP ownership reduces concentration if the top three shareholders are taken, but this is really explained by a lower concentration of ownership for the first one alone (the coefficient for the second and third shareholders is positive but no different from zero (0)).

Per capita GDP seems to increase concentration, even though it has no statistical effect on the first shareholder's share. On the other hand, a deeper market reduces overall concentration. 
TABLE 1

Ownership concentration

(Fixed-effects panel estimation)

\begin{tabular}{lcccc}
\hline \multirow{2}{*}{ Independent variable } & \multicolumn{3}{c}{ Dependent variable: shareholder share } \\
\cline { 2 - 5 } & Top three & First & Second & Third \\
\hline Constant & $-0.7180(0.01)$ & $0.0855(0.75)$ & $-0.6157(0.00)$ & $-0.2234(0.02)$ \\
Dividend payout (-1) & $-0.0099(0.04)$ & $-0.0214(0.00)$ & $0.0127(0.00)$ & $-0.0007(0.69)$ \\
Log (equity) & $0.0076(0.10)$ & $0.0173(0.00)$ & $-0.0053(0.09)$ & $-0.0038(0.03)$ \\
Log (leverage) & $0.0009(0.57)$ & $0.0005(0.78)$ & $-0.0005(0.67)$ & $0.0005(0.39)$ \\
Log (per capita GDP) & $0.0529(0.01)$ & $-0.0167(0.45)$ & $0.0509(0.00)$ & $0.0210(0.01)$ \\
Market capitalization/GDP & $-0.0431(0.00)$ & $-0.0350(0.00)$ & $-0.0085(0.12)$ & $-0.0011(0.73)$ \\
AFP share & $-0.2069(0.00)$ & $-0.2311(0.00)$ & $0.0167(0.56)$ & $0.0121(0.46)$ \\
Public Tender Offer Act dummy & $0.0066(0.24)$ & $0.0185(0.00)$ & $-0.0087(0.02)$ & $-0.0047(0.03)$ \\
2001 transition dummy & $-0.0637(0.00)$ & $-0.0432(0.00)$ & $-0.0157(0.00)$ & $-0.0024(0.43)$ \\
Lagged dependent variable & $0.7784(0.00)$ & $0.7934(0.00)$ & $0.7055(0.00)$ & $0.6977(0.00)$ \\
\hline Adjusted R & 0.9385 & 0.9383 & 0.8482 & 1139 \\
Number of observations & 1139 & 1139 & 0.7988 \\
\hline
\end{tabular}

Source: prepared by the authors.

Note: $P$-value in parentheses.

The Public Tender Offer Act produces an increase in concentration for the first shareholder, but reduces the share of the second and third, making the ownership of companies even more concentrated after its implementation. The transition period seems to induce a lower concentration of ownership, despite the coefficient not being statistically significant for the third shareholder.

In the annex at the end of this paper, we check the robustness of the models estimated above.

First, we estimate a static model for the top three shareholders, not including the lagged dependent variable, to see if the rest of the independent variables are still statistically significant in explaining shareholder shares. As can be seen in table A.1, none of the independent variables has a coefficient that becomes statistically equal to zero (0) in the static model. Moreover, some of them, such as leverage and the Public Tender Offer Act dummy, become significant while retaining the same sign as before. On the other hand, per capita GDP and AFP share increase their effect on the dependent variable.

Next, given the relatively high correlation observed in table A. 2 between the shares of the first, second and third shareholders, we use an instrumental variable method to estimate the shareholder share models, including the other two shareholders' shares for each equation. The results in table A.3, from the panel two-stage least squares estimation, are basically the same for all three shareholders' shares. In the cases of the first and second shareholders, furthermore, the effects from the other two shares are not statistically different from zero (0). In the case of the third shareholder, while the coefficients are statistically significant, they have opposite signs with similar levels. 


\section{VII}

\section{Conclusions}

The effect of dividend payout policy has been to reduce ownership concentration, which could be evidence for its playing a role complementary to that of legal protection and monitoring. It is interesting to note that the reduction in the first shareholder's share more than offsets the increase in the second shareholder's, which in turn highlights the opposing responses of the controlling and following shareholders.

The direct relationship between equity and concentration for the controlling shareholder and the negative effect for the second and third shareholders imply greater concentration at larger companies, with capital increases coming more from the main shareholder than from the inclusion of minority shareholders.

The sign of per capita GDP is positive for the top three shareholders as a group, and for the second and third individually, but is statistically equal to zero (0) for the controlling shareholder, which means that more minority shareholders are coming into the stock market as average income in the country increases.

The positive sign for market capitalization to GDP appears to indicate that a deeper stock market works against concentration.

The role played by pension funds in monitoring and enhancing corporate governance is statistically significant in reducing ownership concentration. This issue is particularly relevant for Latin American countries, given the scale of pensions funds' presence in the region's stock markets.

Although the Public Tender Offer Act achieves its central purpose, the tender offer mechanism increases the concentration of ownership, mainly because of the "residual tender offer" obligation the Act provides for. This assertion does not follow in any way from the econometric analysis above, but in the authors' opinion it does offer a potentially sound explanation for the observed increase in Chilean shareholder concentration since the implementation of the Public Tender Offer Act.

The empirical evidence for statistically significant opposite responses by the controlling shareholder and the next two largest shareholders should sound a note of warning for international comparisons based on a common measure of ownership concentration, when made between stock markets with totally different ownership structures. This issue should be a reminder of the specific characteristics of Latin American stock markets and ownership structures, which need to be taken into account when designing and promoting minority shareholder protection bills, since otherwise the final results may run counter to the original regulatory goals.

ANNEX

TABLE A.1

Ownership concentration: static model

(Fixed-effects panel estimation)

\begin{tabular}{|c|c|c|c|c|}
\hline \multirow{2}{*}{ Independent variable } & \multicolumn{4}{|c|}{ Dependent variable: shares of top three shareholders } \\
\hline & Coefficient & Standard deviation & t-statistic & Probability \\
\hline Constant & -1.7509 & 0.4147 & -4.2218 & 0.0000 \\
\hline Dividend payout (-1) & -0.0222 & 0.0080 & -2.7676 & 0.0057 \\
\hline Log (equity) & 0.0124 & 0.0076 & 1.6398 & 0.1014 \\
\hline Log (leverage) & 0.0071 & 0.0027 & 2.6648 & 0.0078 \\
\hline Log (per capita GDP) & 0.1513 & 0.0332 & 4.5522 & 0.0000 \\
\hline Market capitalization/GDP & -0.0331 & 0.0135 & -2.4509 & 0.0144 \\
\hline AFP share & -0.9088 & 0.0711 & -12.7735 & 0.0000 \\
\hline Public Tender Offer Act dummy & 0.0176 & 0.0091 & 1.9272 & 0.0542 \\
\hline 2001 transition dummy & -0.0505 & 0.0131 & -3.8681 & 0.0001 \\
\hline Adjusted $\mathrm{R}^{2}$ & 0.832033 & & & \\
\hline Number of observations & 1137 & & & \\
\hline
\end{tabular}

Source: prepared by the authors. 
TABLE A.2

Correlation matrix for shareholder shares

\begin{tabular}{llll}
\hline & First & Second & Third \\
\hline First & 1.0000 & & \\
Second & $-0.2356(0.00)$ & 1.0000 & \\
Third & $-0.5347(0.00)$ & $0.3614(0.00)$ & 1.0000 \\
\hline
\end{tabular}

Source: prepared by the authors.

Note: $P$-value in parentheses.

TABLE A.3

Ownership concentration

(Instrumental variable estimation: 25-OLS panel)

\begin{tabular}{|c|c|c|c|}
\hline \multirow{2}{*}{ Independent variable } & \multicolumn{3}{|c|}{ Dependent variable: shareholder shares } \\
\hline & First & Second & Third \\
\hline Constant & $0.1298(0.65)$ & $-0.5814(0.00)$ & $-0.2247(0.02)$ \\
\hline Dividend payout (-1) & $-0.0222(0.00)$ & $0.0129(0.00)$ & $-0.0021(0.23)$ \\
\hline $\log$ (equity) & $0.0170(0.00)$ & $-0.0051(0.10)$ & $-0.0032(0.06)$ \\
\hline Log (leverage) & $0.0006(0.73)$ & $-0.0006(0.60)$ & $0.0009(0.14)$ \\
\hline Log (per capita GDP) & $-0.0199(0.39)$ & $0.0477(0.00)$ & $0.0215(0.00)$ \\
\hline Market capitalization/GDP & $-0.0342(0.00)$ & $-0.0080(0.15)$ & $-0.0014(0.65)$ \\
\hline AFP share & $-0.2266(0.00)$ & $0.0251(0.44)$ & $-0.0188(0.28)$ \\
\hline Public Tender Offer Act dummy & $0.0188(0.00)$ & $-0.0083(0.03)$ & $-0.0032(0.11)$ \\
\hline 2001 transition dummy & $-0.0429(0.00)$ & $-0.0153(0.00)$ & $-0.0038(0.19)$ \\
\hline Lagged dependent variable & $0.7952(0.00)$ & $0.6998(0.00)$ & $0.6367(0.00)$ \\
\hline First shareholder share & & $0.0101(0.55)$ & $-0.0356(0.00)$ \\
\hline Second shareholder share & $0.0789(0.14)$ & & $0.0309(0.08)$ \\
\hline Third shareholder share & $-0.0781(0.49)$ & $0.0873(0.21)$ & \\
\hline Adjusted $\mathrm{R}^{2}$ & 0.93682 & 0.847551 & 0.8271 \\
\hline Number of observations & 1137 & 1137 & 1137 \\
\hline
\end{tabular}

Source: prepared by the authors.

Note: $P$-value in parentheses.

25-oLs: two-stage ordinary least squares. 
Aggarwal, R. and others (2009), "Does governance travel around the world? Evidence from institutional investors", Working Paper Series, No. 2009-8, Ohio, Ohio State University, Charles A. Dice Center for Research in Financial Economics.

Agosin, M. and E. Pastén (2003), "Corporate governance in Chile", Working Papers, No. 209, Santiago, Chile, Central Bank of Chile.

Arellano, M. (2003), Panel Data Econometrics, Oxford, Oxford University Press.

Arellano, M. and S. Bond (1991), "Some tests of specification for panel data: Monte Carlo evidence and an application to employment equations", Review of Economic Studies, vol. 58, No. 2, Wiley Blackwell.

Baltagi, B. (2001), Econometric Analysis of Panel Data, John Wiley \& Sons Ltd.

Burkart, M. and F. Panunzi (2006), "Agency conflicts, ownership concentration, and legal shareholder protection", Journal of Financial Intermediation, vol. 15, No. 1, Amsterdam, Elsevier.

Claessens, S., S. Djankov and L.H.P. Lang (2000), "The separation of ownership and control in East Asian corporations", Journal of Financial Economics, vol. 58, No. 1-2, Amsterdam, Elsevier.

Davis, E. (2002), "Institutional investors, corporate governance and the performance of the corporate sector", Economic Systems, vol. 26, No. 3, Amsterdam, Elsevier.

Demsetz, H. and K. Lehn (1985), "The structure of corporate ownership: causes and consequences", Journal of Political Economy, vol. 93, No. 6, Chicago, University of Chicago Press.

Faccio, M. and L.H.P. Lang (2002), "The ultimate ownership of Western European corporations", Journal of Financial Economics, vol. 65, No. 3, Amsterdam, Elsevier.

Faccio, M., L.H.P. Lang and L. Young (2001), "Dividends and expropriation", American Economic Review, vol. 91, No. 1, Nashville, Tennessee, American Economic Association.

Foley, F. and R. Greenwood (2010), "The evolution of corporate ownership after IPO: the impact of investor protection", Review of Financial Studies, vol. 23, No. 3, Oxford, Oxford University Press.

Gillan, S. and L.T. Starks (2003), "Corporate governance, corporate ownership, and the role of institutional investors: a global perspective", Journal of Applied Finance, vol. 13, No. 2.

Iglesias-Palau, A. (2000), "Pension reform and corporate governance: impact in Chile", Abante, vol. 3, No. 1, Santiago, Chile, Catholic University of Chile.

Khanna, T. and Y. Yafeh (2007), "Business groups in emerging markets: paragons or parasites?", Journal of Economic Literature, vol. 45, No. 2, Nashville, Tennessee, American Economic Association.

Kim, K.A., J.R. Nofsinger and P. Kitsabunnarat-Chatjuthamard (2008), "Large shareholders, board independence, and minority shareholder rights: evidence from Europe", Buffalo Legal
Studies Research Paper, No. 2008-23 [online] http://ssrn.com/ abstract=1254655 or http://dx.doi.org/10.2139/ssrn.1254655.

La Porta, R. and others (1998), "Law and finance", Journal of Political Economy, vol. 106, No. 6, Chicago, University of Chicago Press.

La Porta, R., F. Lopez-de-Silanes and A. Shleifer (1999), "Corporate ownership around the world", The Journal of Finance, vol. 54, No. 2, American Finance Association.

Lazen, V. and A.C. Sepúlveda (2004), "Desarrollo de las tomas de control corporativo en Chile después de la Ley de opas", Documento de Trabajo, No. 4, Santiago, Chile, Office of the Superintendent of Securities.

Lefort, F. (2007), "La contribución de las administradoras de fondos de pensiones al gobierno societario de las empresas chilenas", Santiago, Chile, unpublished.

Lefort, F. and E. Walker (2007), "Do markets penalize agency conflicts between controlling and minority shareholders? Evidence from Chile", The Developing Economies, vol. 45, No. 3, Wiley.

(2000), "Ownership and capital structure of Chilean conglomerates: facts and hypotheses of governance", Abante, vol. 3, No. 1, Santiago, Chile, Catholic University of Chile.

Lefort, F. and F. Urzúa (2008), "Board independence, firm performance and ownership concentration: evidence from Chile", Journal of Business Research, vol. 61, No. 6, Amsterdam, Elsevier.

Musacchio, A. (2007), "Stock market development, ownership concentration, and investor protections in Brazil, 1890-1950", Harvard Business School, unpublished.

OECD (Organisation for Economic Cooperation and Development) (2010), "Characteristics of institutional investors in Latin American Markets", White Paper on Strengthening the Role of Institutional Investors in Latin American Corporate Governance, final draft [online] http://www.oecd.org/corporate/ $\mathrm{ca} /$ corporategovernanceprinciples/46200302.pdf

(2007), "Institutional investors and corporate governance in Latin America: challenges, promising practices and recommendations", Paris. (2004), oECD Principles of Corporate Governance, Paris, April [online] http://www.oecd.org/dataoecd/32/18/31557724.pdf.

Rojo, A. and Garrido, J.M. (2002), "Institutional investors and corporate governance: solution or problem?", Company Law and Financial Markets, K.J. Hopt and E. Wymeersch (eds.), Oxford, Oxford University Press.

Starks, L.T. (2000), "Corporate governance and institutional investors: implications for Latin America", Abante, vol. 2, No. 2, Santiago, Chile, Catholic University of Chile.

Weiss, C. and A. Richter (2010), "Determinants of ownership concentration: the importance of firm-, industry- and countrylevel factors", European Business School Research Paper, No. 10-05, Wiesbaden, EBS Business School. 